\title{
Sports Facilities and Local Government Policy: A Case Study in West Java, Indonesia
}

\author{
Didik Subhakti Prawira Raharja ${ }^{1, *}$, Nurlan Kusmaedi², Amung Ma'Mun², Berliana ${ }^{2}$ \\ ${ }^{1}$ Department of Physical Education, Faculty of Teacher Training and Science Education, Universitas Majalengka, Majalengka, \\ Indonesia \\ ${ }^{2}$ Faculty of Sports and Health Education, Universitas Pendidikan Indonesia, Bandung, Indonesia
}

Received April 23, 2021; Revised June 16, 2021; Accepted July 18, 2021

\section{Cite This Paper in the following Citation Styles}

(a): [1] Didik Subhakti Prawira Raharja, Nurlan Kusmaedi, Amung Ma'Mun, Berliana, "Sports Facilities and Local Government Policy: A Case Study in West Java, Indonesia," International Journal of Human Movement and Sports Sciences, Vol. 9, No. 4A, pp. 71 - 76, 2021. DOI: 10.13189/saj.2021.091312.

(b): Didik Subhakti Prawira Raharja, Nurlan Kusmaedi, Amung Ma'Mun, Berliana (2021). Sports Facilities and Local Government Policy: A Case Study in West Java, Indonesia. International Journal of Human Movement and Sports Sciences, 9(4A), 71 - 76. DOI: 10.13189/saj.2021.091312.

Copyright@2021 by authors, all rights reserved. Authors agree that this article remains permanently open access under the terms of the Creative Commons Attribution License 4.0 International License

\begin{abstract}
The completion of the sports facilities available in each region is not evenly distributed, apart from the 4th largest population in the world, the various sports activities carried out by the community must be supported by means of transport. Support, the availability of sports facilities is affected by the policies of each regional government. SPOrT (Integrated Sports Development Center) Jabar Arcamanik is a sports complex owned by the West Java Regional Government. The aim of this article is to provide an overview of the emergence of local government policies in the provision of sports facilities. The case study method used in this study is the semi-structured interview and observation as a data collection tool, as well as the participants involved, namely the head of the relevant department and the management of the sports facilities. The presence of sports facilities is the implementation of local government policies through the transformation of national and regional development plans, in order to bridge the gap between regions in terms of infrastructure development. Infrastructures for sports facilities bring cultural heritage and benefits to the community. Therefore, the construction of sports facilities can be achieved when policy makers have a desire and understanding of regional regeneration associated with regional development, the allocation of budgets related to the needs are determined and adjusted to current regulations so that the benefits from the availability of sports facilities can be felt by the community.
\end{abstract}

Keywords Sports Facilities, Local Government, West Java Indonesia, SPOrT Jabar, Sports Policy

\section{Introduction}

In the last three decades, the service delivery model used by the public sector has undergone significant reforms. In many countries, such as the Netherlands, Canada, New Zealand, the United States even including Britain and Australia, and local governments at all levels, including Australia, public sector reforms have been noted [1]. The opening of new sports facilities will increase the attendance rate of these new sports facilities. Fans will find it easier to watch matches and more efficiently use other facilities, such as concessions and parking lots for new facilities [2]. Sport provides various benefits, but not all people have the same opportunity to do physical activity due to the unequal provision of sports facilities in each region which are influenced by local government policies.

Local governments have the authority to make policies in support of the central government. Indeed the government must observe the principle of decentralization, autonomy, community participation, professionalism, partnership, transparency, and accountability. The system for managing, fostering, and developing national sports is 
regulated in the spirit of regional autonomy policies to realize regions and communities' capacity to develop sporting activities independently. By building stadiums and public sports facilities, local governments demonstrated their efforts to promote state urbanization and repositioning plans, resulting in cities investing large amounts of public funds in development [3].

In terms of development, regarding the competition between cities where specific cultural projects (including sports projects) are used to achieve rebranding and economic development, cultural assets have become a significant resource. Even sports and sports facilities can be used to regenerate the city's economy. This argument is also in line with the extensive discourse on urban competitiveness and the provision of facilities that attract new forms of capital and provide recreational opportunities that improve the population's quality of life. Improve people's lives, create jobs, and increase business investment; cities around the world are struggling and competing with each other by shifting management from an industrial economy to a service-based economy [2].

The construction of sports facilities is inseparable from the political role of policymakers. In the broader social environment, the sports policy process has its function. In line with Houlihan, it was essential to understand how it worked and its background in developing sports policy [4]. This refers, among other things, to the configuration of the department in which sports policy resides and to organizational behavior and other developments towards sports policy.

In the process, events that have occurred in the last few decades have influenced the policy-making process. We trace the presence of sports policy as a result of other policy areas, which can be characterized by developments in political interests and policies that coincide with structural expansion, to its current position as the central sustainable policy by following the intervention and control of the central government [5].

In general, sport is regarded as a policy instrument that is relatively cost-effective because it is built based on voluntary organizations. Changes in sports policy are influenced by changes in financial reality, changing the organizational structure in the city, and national policy changes [6] Although activities sports policies locally remained essentially unchanged despite the development of exogenous reposition sports policy as a social force developing $[4,6]$. Thus, to provide sports facilities for all people, it is necessary to consider the types of sports activities that have a reasonably strong history and can be used as recreational activities as well as swimming and walking [1].

The difficulty of allocating a budget for the construction of sports facilities needs to be balanced with other socially oriented policies. Creating sports facilities and infrastructure that are adequate is a reference in sport policy objectives socially-oriented so that the amount of the budget remains in use for a sustainable means [6]. Even the development of sports facilities, which are mainly carried out in China, has other objectives that become strategic references by local governments: (1) improve competitiveness among regions, with continued development and growth and (2) building "human-centered" buildings that can position the city in a symbolic for profit [3]. This paper aims to provide a different perspective on how local government policies are in building sports facilities. Over the last few decades, public policies for sports development are increasingly prominent; this can be seen in several countries such as Britain, Singapore, the United States, Germany, and China. The existence of various problems related to other policies such as health, education, and community development, social inclusion has become a differentiator for each country in updating sports policies, especially in achieving the success of elite sports [7]. In other cases, the government, with its intervention in sports, has also been progressing in adjusting the regulations that apply in developing countries (such as license coach, controlling doping, the management of broadcasting rights, and licensing health club), increased levels of funding, more and more cities that bid for a host, host the summer Olympic Games and increase international support for the World Anti-Doping Code $[4,8]$.

In another case, the number of sports activities carried out and the number of people involved in sports participation will not help much in the development of sports in a sustainable manner. When there are limited implementing units at the regional level, it will be difficult for the government to promote sports for all people. To help people develop exercise habits, governments need to change how they encourage exercise effectively; otherwise, taxpayers' money will likely be wasted [9]. Various governments have attempted, in recent years, to use sport as a social engineering instrument to reduce juvenile abuses, reduce obesity among young people, and achieve greater social inclusion in marginalized groups [4].

Even though various development programs are available to the community, local government decision-makers are constrained by choosing programs and allocating resources. Other studies in Europe reveal that sports facilities impact economic improvement, ranging from development involving workers, rental places, or costs incurred by the community when exercising or watching matches $[10,11]$. Gunduz and Tehemar state during the last two decades in the global environment, the construction of sports facilities growing dramatically due to the number of sporting events increased significantly [12].

Although in practice, sports policy is always linked to other approaches, in line with other policy domains, which can create opportunities to promote the values embodied in sport and access to additional public resources for sport 
[4]. Little evidence from sports policy reports describing the effects of exercise, even other evidence for achieving the goals of sports policy is unknown. As a result, all admitted that they did not know the extent to which the policy initiative was effective. At least there is an indication that policy initiatives have contributed to achieving the goals of sports policy. Hoekman and Van der Maat prove that only $10 \%$ of cities can prove to be effective and contribute [13]. Although it is difficult to demonstrate the contribution value of the policy of this sport in the evaluation, the cities that implement the sport believe that no other policy areas that can provide the same effect on the sport, this study aims to provide an overview of how local government policies provide sports facilities.

\section{Method}

This study used a qualitative approach with a case study method involving the West Java Arcamanik Integrated Sports Development Center (SPOrT) as a research subject. The center is a sports complex facility managed and owned by the West Java regional government. The instruments used were observation and semi-structured interviews. To reveal how local government policies in providing sports facilities, in-depth semi-structured interviews were conducted, mainly to obtain the perceptions of the interviewed participants. In contrast, the participants involved were the head of the youth and sports office representing the local government, the manager of sports facilities, and visitors to sports facilities by applying the snowball sampling technique. The interview itself was conducted following the availability of informant time with a duration of 30-60 minutes, and the identity of the informant could be kept confidential following research ethics, semi-structured guidelines were made regarding why and how the policy of building sports facilities, furthermore this semi-structural design provides an opportunity to be able to dig deeper when there is other information that appears during the interview. Moreover, the interview results were transcribed into a document carried out by the coding process to be analyzed and produced several relevant categories of comments related to the research question.

\section{Results and Discussion}

This section presents and discusses the research results related to how and why government policies were born in providing sports facilities - followed by discussing how the procedure for the development of sports facilities provides benefits that can be felt by the community. Several themes emerged based on the analysis of interview data, including regional regeneration, budget allocation, and policy implementation.

\section{Regional Regeneration}

SPOrT Jabar Arcamanik was known as a horse racing area, which has left its memories by naming the road as a horse racing road. It is known as the horse racing area because a horse racing facility was built in 1974 by a group of horse-riding lovers [14]. This is reinforced by the results of the interview, which said:

"I saw there was an area, besides the golf course was for horse riding, but the riding area was not maintained even though it was taken care of by the pordasi. Because during the dry season to play golf, the dust may have horse dung, maybe even when playing golf is inhaled, and it is not good for the environment so it needs regulation (informant 1)".

Besides, during this period, policymakers acknowledged that various development problems such as economic development, environmental management, and social issues could be resolved through sports policies [15].

Although the initial construction was designed as a training ground for West Java student-athletes, the facility was converted to function as a place for various activities, such as sports activities, music concerts, seminars, and other events. He also expressed:

"Now there is a new concept in West Java that Bandung city becomes a sports city, and makes sports tourism, not just people exercising, so the benefits are huge. It is very clear to improve achievement because regional student-athletes and the community can take advantage of these facilities (informant 2)".

This is in line with Soebbing et al. [2]. The benefits a city generates by hosting regional teams and various sporting events organized will give an image and quality of life. The West Java SPOrT is a sports facility complex in which there is a West Java youth and sports office in Indonesia.

One of the most valuable points of the construction of sports facilities is the legacy value that can be given to future generations. The Olympic Stadium emerged as a great testimony to the evolution of the sport and a witness to the past and in today's society. They must be considered an extraordinary legacy; all people in the world will welcome and know the location of the event through international events. [16].

\section{Budget Allocation}

Starting in 2010, the construction of these facilities took place in stages because it was related to the availability of funds that could not be directly issued by the West Java regional government considering the large budget allocation until now only the youth and sports offices, stadiums, and athletic tracks were available. The youth center building, the agile fighting building, the Satria building, the gymnasium, the sand volleyball court, the softball field, and the Pencak silat hermitage. 
Funding for infrastructure development is often justified in a sports stadium or arena for its benefits. The resulting benefits are in the form of an economic impact, where there is a turnover of money which economically includes things such as costs incurred by fans at sporting events, athlete income incurred in the community, and cash generated from selling tickets and souvenirs; as well as non-economic impacts which include the social effects felt by the community, which provides experience through participating in sporting events and a sense of pride for regional teams by showing their identity [17].

Understanding the concept of thinking behind the urge to take up this position is necessary, even without any difficulty and receiving direct help from the committee chair at the time. That point, I would say, this is a fair budget. Allocations are made, but the challenge arises and the interpretation of the nature of a project, and this sometimes becomes a challenge in itself. I want this to turn this into a quality (Informant 1 ).

Yes, the problem is the budget, so the building is not all at once. It can be large, so the government is planning it in stages. Now, many buildings are not finished, such as the athletes' homestead, the study center, the sports school. Even though the master plan and market plan already exist, and they must be built, it remains what the government does now (informant 2).

Thus it is clear that the construction of sports facilities cannot be separated from the political role of policymakers. About the construction of sports facilities is a removal process of budget allocation, which is based on the program priorities to be achieved. It is in line with the expression despite various development programs available to the public, and local government decision-makers are constrained by how they choose the schedule and allocate resources [18], so that the implementation of public policy in sports must be accompanied by building a communication system, a system of authority (power), a system of trust (trust), a value system [19]

\section{Policy Implementation}

In line with the West Java government's vision and mission at that time with the slogan "Jabar Kahiji" (West Java being the number one province) to achieve this goal, it is necessary to support facilities that can support West Java athletes to become champions. Development of Sport Jabar district built on 20 hectares of land during the reign of Ahmad Heryawan in line with Law No. 3 of 2005 on National Sports System; Explanation of the vision, mission, direction of the National Long Term development 2005-2025; Local Regulation 2004 No. 1 West Java province on the Strategic Plan of the Government of West Java Province.

Another expression was conveyed by "Translating the governor's RPJMD (informant 1). This foundation is strengthened by the Republic of Indonesia Government Regulation No. 18 of 2007 concerning sports funding. It states that both the central and local governments are responsible for improving the quality and quantity of sports facilities and infrastructure.

The assumption that policies will change due to past experiences or new information is the basis for policy formation and change. Thus, Understanding policy has much in common with the flow-dependent concept, which suggests that in determining policy, the initial decision will determine substantially for the following procedure in the future [8]. Furthermore, Newman, where executive power seems to be distributed among various institutions at the local level, the government applies the principle of reward and punishment in implementing policies and holds control from top to bottom with tight fiscal controls [5].

They are using the theory of public administration where the public sector, in the form of sports facilities which is the main contributor to use, can be utilized through various types of policies. As a consideration in the development, operation, and maintenance costs of sports facilities, to produce a significant contribution, the local government is selected [20].

\section{Reflection: Limitations in Sports Policy Development}

The sports sector's development targets are increasing the harmony of various sports policies at the national and regional levels, increasing the health and physical fitness of the community and sports achievements, and developing support for sports facilities and infrastructure for the community following superior regional sports [21]. This needs to be fought for considering that people have the same rights in using public facilities in the form of facilities for exercising considering the enormous benefits provided.

Furthermore, sports facilities improvement program is intended to provide, organize, and build sports facilities and infrastructure to support the promotion and development of sports, as well as sports achievement, while the main activities to be carried out include, a. increasing the participation of the business world and society to support sports funding and coaching, and b. support for the development of sports facilities and infrastructure in the province and district/city in accordance with regional priority sports [21]. It is hoped that Sport Jabar facilities can be followed by other regions and become a pilot project to provide sports facilities that are evenly distributed in each area. Then the budget is not the main problem in determining the policy for the development of sports facilities, but rather the desire and understanding of the meaning given by sport itself from policymakers. 


\section{Conclusions}

Overall, it can be concluded that the development of sports facilities has a history related to regional development and how the local government can translate any applicable laws and regulations and regional development strategic plans. Judging from the rules, facilities should be available in each region. Ideally, the construction of facilities in an environment that is not far from the community so that its utilization is more optimal and needs to be supported by other facilities so that something can be obtained from both the manager and the user.

The presence of local governments in providing public facilities is inseparable from the transfer of available budget allocations. The size of the budget allocations is often a problem in the regional development process. Building sports facilities must be a priority included in reducing the level of public health. As a study material in formulating policies in the provision of sports facilities, it is necessary to consider the impacts both economically and socially so that the presence of the facilities can improve the welfare of the community. Policymakers are increasingly convinced that sport can be used to solve various problems related to multiple policies of urban development and regeneration [15].

The construction of sports facilities for SPOrT Jabar is a provider of training venues and an open space capable of accommodating many visitors, both sporting and official activities and various non-sporting events, which can have a good impact on health, social and economy. So there is great hope that the development of sports facilities in the form of a complex SPOrT can be realized in every region that involves local government policies considering the many benefits generated from this development. Further research can be carried out by comparing various sports facilities and exploring the benefits derived from their availability.

\section{Acknowledgment}

Acknowledgments The author goes to the Ministry of Education and Culture, Higher Education, which has funded this research through scholarships BPP-DN, the West Java Provincial Youth and Sports Service who has permitted to be able to carry out this research, and the faculty of teacher training and education science, Universitas Majalengka which has provided support moral and material to the author, as well as all those who have been involved in this research.

\section{REFERENCES}

[1] McGrath R. A discourse analysis of Australian local government recreation and sport plans provision for people with disabilities. Public Manag Rev 2009;11:477-97. https://doi.org/10.1080/14719030902989540.

[2] Sobbing BP, Mason DS, Humphreys BR. Novelty effects and sports facilities in smaller cities: Evidence from Canadian hockey arenas. Urban Stud 2015;53:1674-90. https://doi.org/10.1177/0042098015576862.

[3] Xue H, Mason DS. Stadium Games in Entrepreneurial Cities in China: A State Project. J Glob Sport Manag 2019;4:185-209. https://doi.org/10.1080/24704067.2018.1 531246.

[4] Houlihan B. Public sector sport policy: Developing a framework for analysis. Int Rev Sociol Sport 2005;40:16385. https://doi.org/10.1177/1012690205057193.

[5] Phillpots L, Grix J, Quarmby T. Centralized grassroots sport policy and "new governance": A case study of county sports partnerships in the UK - unpacking the paradox. Int Rev Sociol Sport 2011; 46:265-81. https://doi.org/10.1177 /1012690210378461.

[6] Hoekman R, Elling A, van der Poel H. Local Policymaking in Sport: Sport Managers' Perspectives on Work Processes and Impact. J Glob Sport Manag 2019; 0:1-23. https://doi.org/10.1080/24704067.2018.1537682.

[7] Houlihan B. Sport, national identity and public policy. Nations Natl 1997; 3:113-37. https://doi.org/10.1111/j.135 4-5078.1997.00113.x.

[8] Green M, Collins S. Policy, Politics and Path Dependency: Sport Development in Australia and Finland. Sport Manag Rev 2008; 11: 225-51. https://doi.org/10.1016/S1441-352 3(08)70111-6.

[9] Huang Y-W, Tan T-C. Sport-for-All Policy in Taiwan: a case of ongoing change? Asia Pacific J Sport Soc Sci 2015;4:85-98. https://doi.org/10.1080/21640599.2015.105 1367.

[10] Chapin TS. Identifying the Real Costs and Benefits of Sports Facilities. J Chem Inf Model 2002;53:1689-99. https://doi.org/10.1017/CBO9781107415324.004.

[11] Richardson SA. Does stadium construction create jobs and boost incomes? The realized economic impacts of sports facilities in New Zealand. New Zeal Econ Pap 2016;50:153-76. https://doi.org/10.1080/00779954.2015.1 043932 .

[12] Gunduz M, Tehemar SR. Assessment of delay factors in the construction of sports facilities through multi-criteria decision making. Prod Plan Control 2019;0:1-12. https://doi.org/10.1080/09537287.2019.1704903.

[13] Hoekman, R., van der Roest, J.-W., \& van der Poel, H. (2017). From welfare state to participation society Austerity measures and local sport policy in the Netherlands. International Journal of Sport Policy and Politics.pdf n.d.

[14] Pamelpams. Pacuan Kuda Arcamanik Tinggal Kenangan 2014.

[15] Davies LE. Sport and economic regeneration: A winning combination? Sport Soc 2010; 13:1438-57. https://doi.org/10.1080/17430437.2010.520935.

[16] Kuri M, Teller J. Olympic stadiums and cultural heritage: 
On the nature and status of heritage values in large sports facilities. Int J Hist Sport 2015;32:684-707. https://doi.org/10.1080/09523367.2015.1037745.

[17] Grieve J, Sherry E. Community benefits of major sport facilities: The Darebin International Sports Centre. Sport Manag Rev 2012; 15: 218-29. https://doi.org/10.1016/j.sm r.2011.03.001.

[18] Friedman MT, Mason DS. A stakeholder approach to understanding economic development decision making: Public subsidies for professional sport facilities. Econ Dev Q 2004; 18: 236-54. https://doi.org/10.1177/08912424042 65795 .
[19] Irfan, Rusdin, Yanti, S., Shandi, S. A., \& Ihsan. (2021) Public policy for financing the practice of physical education. International Journal of Human Movement and Sports Sciences, 9(2), 209-218. DOI: 10.13189/saj.2021.090207

[20] Iversen EB, Cuskelly G. Effects of different policy approaches on sport facility utilisation strategies. Sport Manag Rev 2015; 18:529-41. https://doi.org/10.1016/j.smr .2014.12.004.

[21] Ma'mun A. PEMBANGUNAN OLAHRAGA NASIONAL (Konsep, Strategi dan Implementasi). 2017. 